Instructions for authors, subscriptions and further details:

http://rasp.hipatiapress.com

\title{
Adult Education in Neoliberal Times: Policies, Philosophies and Professionalism
}

Everton M. Batisteti

1) Universidade Federal de Sao Carlos. Brazil

Date of publication: July $30^{\text {th }}, 2019$

Edition period: July 2019- December 2019

To cite this article: Batisteti, E.M. (2019). Adult Education in Neoliberal Times: policies, Philosophies and Professionalism. [Review of the book]. Research on Ageing and Social Policy, 7(2), 448-450. doi:

10.4471/rasp.2019.4322

To link this article:_http://dx.doi.org/10.4471/rasp.2019.4322

\section{PLEASE SCROLL DOWN FOR ARTICLE}

The terms and conditions of use are related to the Open Journal System and to Creative Commons Attribution License (CCAL). 


\section{Review}

Bowl, M. (2017). Adult Education in Neoliberal Times: Policies, Philosophies and Professionalism. Cham, Switzerland: Palgrave Macmillan. 200 pp. ISBN 9783319508825.

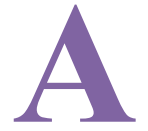

dult education is characterized by a diversity that crosses different aspects: philosophical and political conception, purpose, target audience, objectives, public policies, professionalism and values. All these elements are present in the book of Marion Bowl - Senior Lecturer in Education in the School of Education of the University of Birmingham entitled 'Adult Education in Neoliberal Times: Policies, Philosophies and Professionalism', re-published by Palgrave Macmillan.

Bowl's approach to the subject is evident from its title: it is critical of neoliberal policies on the field of education, particularly on adult education. Notwithstanding, the author warns the book intends to go beyond "the critique of the consequences of neoliberalism and the discussion of tactics of avoidance, accommodation and micro-resistance" (p.3), leading the discussion of the theme to two paths; one that points toward adult education advocacy strategies for the public good and another that articulates an approach that is theoretically and politically engaged.

The first part of the book called "Historical and Political Contexts for Adult Education" brings in its first chapter an introduction of the proposed work, highlighting the main historical and political points that surround the theme. Chapter two presents a brief and forceful analysis of the transformation of the concept of adult education to lifelong education, emphasizing the role of neoliberal policies. The third chapter allows the reader to know and compare the national contexts of New Zealand and England in reference of adult education. Completing the first part of the book, chapter four takes up an interesting discussion about the professionalism, professionalization, training and development of the agent involved with adult education.

In the second part of the book, Adult Educators' Working Lives Researched, the reader will find different voices of adult educators in order 
to understand this diverse field of theory and practice. From 2011 to 2013, Bowl conducted 62 interviews with adult educators, divided equally between England and New Zealand. It is from the analysis and comparison of the biography of these participants that the researcher makes her reflections and syntheses on the values, professional conceptions, philosophies and practices, and the relationship with the political context - national and international - that touches the thematic. As an introduction to this part, chapter five provides an overview of how research was conducted. Chapter six addresses the career and social role of the adult educator. Accordingly, chapter seven brings the values and beliefs that are embodied by these educators. The dilemma between accommodation and resistance is explored in chapter eight, evidencing a more complex field than what is covered by scientific literature. Chapter nine explores the strategies of advocacy used by these educators, indicating an array of actions, whether successful or insubstantial in their political, theoretical and philosophical conceptions.

Chapter ten, which closes the book, contains the syntheses relating to which paths and perspectives can adult education - asa public good for the development of all and never apolitical - take for the future. It emphasizes the features of successful advocacy and campaigning strategies: they are inclusive; have clearly articulated aims developed through debate and consultation; links with underlying political and economic causes; able to respond quickly and coherently to policy developments, promote 'learning in action'; link deliberately with other campaigns; use research to generate evidence; maintain independence from government influence; actively rebut the opposition's arguments; highly interactive; build on the expertise of all involved (p.168).

To summarize, the book is recommended to all those interested in adult education in a critical perspective that addresses the political and historical contradictions of education in neoliberal times, and those who are interested in professionalism and professionalization of education. This book compiles with other critical authors a perspective based on reality, which brings objective recommendations for an education engaged with theory and politically committed as a public good.

Everton Madaleno Batisteti, Universidade Federal de Sao Carlos. 